2014, volume 3, issue 1

Bartniczak B. (2014). State aid as a tool encouraging production of energy from renewable sources. Copernican Journal of Finance \& Accounting, 3(1), 19-31. http://dx.doi.org/10.12775/CJFA.2014.002

\author{
Bartosz BARTNICZAK* \\ Wrocław University of Economics
}

\title{
STATE AID AS A TOOL ENCOURAGING PRODUCTION OF ENERGY FROM RENEWABLE SOURCES
}

Keywords: state aid, renewable energy.

J E L Classification: H23.

Abstract: Providing aid because of its negative impact on competition in the European market is allowed only for specific purposes that are defined in legislation. One of the areas where state aid is permissible is aid to protect the environment, and within it we can provide assistance to support the production of renewable energy sources. The rationale for the provision of such aid is the fact that the production of energy from renewable sources is more expensive than the production of energy from conventional sources. On the other hand, it is more environmentally friendly. The European Commission has decided aim before Member States of increasing the use of renewable energy sources. One of the instruments contributing to increased production of renewable energy is state aid. The article presents the justification for granting state aid in the field of renewable energy sources, indicates what are the conditions for the granting thereof. Also shown is an example of Polish aid program on support for biofuel production.

\section{POMOC PUBLICZNA JAKO NARZĘDZIE \\ WPIERAJĄCE PRODUKCJĘ ENERGII ZE ŹRÓDEE ODNAWIALNYCH}

Słowa kluczowe: pomoc publiczna, odnawialne źródła energii.

Date of submission: February 3, 2014; date of acceptance: March 19, 2014.

* Contact information: bartosz.bartniczak@ue.wroc.pl, Faculty of Economy, Management and Tourism in Jelenia Góra, Wrocław Univeristy of Economics, Nowowiejska 3, 58-500 Jelenia Góra, Poland, phone: 757538257. 
Klasyfikacja J E L: H 23.

Abstrakt: Udzielanie pomocy publicznej ze względu na jej negatywny wpływ na konkurencję na rynku europejskim jest dopuszczalne tylko na ściśle określone cele, które są zdefiniowane w przepisach prawnych. Jednym z obszarów gdzie udzielanie pomocy publicznej jest dopuszczalne jest ochrona środowiska, a w ramach niej można udzielać pomocy na wspieranie produkcji odnawialnych źródeł energii. Uzasadnieniem udzielania tego rodzaju pomocy jest fakt, że produkcja energii ze źródeł odnawialnych jest droższa niż produkcja energii ze źródeł konwencjonalnych. Z drugiej jednak strony jest ona bardziej przyjazna dla środowiska. Dlatego Komisja Europejska postanowiła przed państwami członkowskimi cel polegający na zwiększeniu wykorzystania odnawialnych źródeł energii. Jednym z instrumentów przyczyniających się do zwiększenia produkcji energii odnawialnej jest pomoc publiczna. W artykule zaprezentowano uzasadnienie udzielenia pomocy publicznej w obszarze odnawialnych źródeł energii, wskazano jakie są warunki jej udzielania. Pokazano także przykład polskiego programu pomocowego dotyczącego wsparcia produkcji biopaliw.

Translated by Bartosz Bartniczak

\section{INTRODUCTION}

State aid is a term introduced by the European Commission and regulated in Art. 107 paragraph 1 TFEU (TFEU). To the measure could be regarded as State aid under this article must be met including four conditions: intervention by the state or through state resources, the intervention gives the recipient an advantage on a selective basis, competition has been or may be distorted and the intervention is likely to affect trade between Member States.

The article presents the concept of state aid. Indicated conditions that justify the granting of state aid in support of renewable energy sources. An analysis of legal solutions allowing state aid to renewable energy sources was made. In the last part shows an example of Polish aid program under which state aid is granted to support the production of biofuels.

\section{THE RESEARCH METHODOLOGY AND THE COURSE OF THE RESEARCH PROCESS}

Research in article were carried out in several stages. In the first stage defined the concept of state aid. Then sought to answer the question why it is reasonable to give the state aid in the area of renewable energy sources. In the next stage of the analysis of the legislation authorizing the granting of aid for the promotion of renewable energy sources. In the last stage analyzed the aid program by which support is provided in the area of renewable energy sources. 


\section{THE CONCEPT OF STATE AID}

Contemporary economic reality is so complicated that it is difficult to imagine the functioning of the market mechanism in isolation from the state. One of the instruments through which the state can intervene in a market economy is state aid. It shall be considered part of the economic state intervention, which aims to stimulate positive economic developments or prevention of negative processes (Modzelewska, Pełka 2001,33). This aid can be considered as a tool in the hands of public authorities, which is used to achieve different objectives and tasks of social and economic policy. Governments grant state aid for many reasons: economic, social, political and strategic (Hancher, Ottervanger, Slot 2012,30 ). Despite the widespread occurrence the phenomenon of state aid there is no legal (normalized by law) the definition of that term.

Issues concerning the admissibility of state aid are governed by Art. 107-109 Treaty of Functioning European Union (Consolidated version of the Treaty). Article 107 paragraph. 1 indicates only that „save as otherwise provided in the Treaties, any aid granted by a Member State or through State resources in any form whatsoever which distorts or threatens to distort competition by favouring certain undertakings or the production of certain goods shall, in so far as it affects trade between Member States, be incompatible with the internal market". Analysis of the provisions of this article allows to conclude that it would be prohibited to provide aid if the conditions referred to therein are together fulfilled. For these circumstances include the transfer of state resources, obtaining economic benefits, the selective nature and occurrence of the effect on competition and trade. In Article 107 paragraph. 2, we can read that compatible with the internal market:

a) aid having a social character, granted to individual consumers, provided that such aid is granted without discrimination related to the origin of the products concerned;

b) aid to make good the damage caused by natural disasters or exceptional occurrences;

c) aid granted to the economy of certain areas of the Federal Republic of Germany affected by the division of Germany, in so far as such aid is required in order to compensate for the economic disadvantages caused by that division.

While, Art. 107 Paragraph 3 indicates the types of aid that may be considered compatible with the internal market. These include: 
a) aid to promote the economic development of areas where the standard of living is abnormally low or where there is serious underemployment, and of the remote regions referred to in Article $349^{1}$, in view of their structural, economic and social situation;

b) aid to promote the execution of an important project of common European interest or to remedy a serious disturbance in the economy of a Member State;

c) aid to facilitate the development of certain economic activities or of certain economic areas, where such aid does not adversely affect trading conditions to an extent contrary to the common interest;

d) aid to promote culture and heritage conservation where such aid does not affect trading conditions and competition in the Union to an extent that is contrary to the common interest;

e) such other categories of aid as may be specified by decision of the Council on a proposal from the Commission.

Support that objectives are renewable energy are awarded to the exclusion defined in Art. 107 Paragraph 3 point. c based on guidelines on state aid for environmental protection.

\section{JUSTIFICATION FOR GRANTING STATE AID IN PRODUCTION ENERGY FROM RENEWABLE SOURCES}

Environment protection is a desirable direction for granting state aid. Complementarity of environmental policy and state aid policy is expressed in the competitive pressures that encourages entrepreneurs to use less polluting production technologies seek greener products (Brodecki 2004, 124). And just such a practical example is to support the production of renewable energy.

In the Guidelines on State aid for environmental protection can read that the purpose of providing support in the area of renewable energy sources is to create a system of incentives which will increase the share of production of this type of energy. Increasing the use of renewable energy sources is a priority for the European Union both energetic, economic and environmental. Increasing the share of energy produced from renewable sources will help to reduce greenhouse gas emissions. That is why the European Union has set a target of

${ }^{1}$ For remote regions include French Guiana, Guadeloupe, Martinique, Réunion, Saint-Barthélemy, Saint-Martin, the Azores, Madeira and the Canary Islands. 
achieving a $20 \%$ share of renewable energy in total energy consumption by 2020 , including a $10 \%$ share of biofuels in fuel consumption. Greenhouse gas emissions or climate change caused by them are one of the types of externalities. This is due to the fact that entrepreneurs do not assume (do not include in their decisions) present and future costs of their emissions (Ptak 2013, 276). According to N. Stern greenhouse gas emissions is the greatest market failure "which world has ever seen" (Stern 2011, 27). Therefore, there is need to support the production of energy from renewable sources. One of the instruments by which this can be achieved is the state aid. The cost of energy production from renewable sources is higher than from traditional sources. Therefore, state aid should encourage entrepreneurs to invest in the production of energy from renewable sources. The amount of support may not exceed the difference between the cost of production of electricity from renewable energy sources and the market price of electricity (Pełka, Stasiak 2002, 114). This causes considerable difficulties in competing in the market for renewable energy generators, and indeed often even impossible to enter the market and start-up of business. In recent years, however, there are new technologies thanks to them the production of renewable energy becomes cheaper and thus easier for renewable energy producers is to compete on the market. Factor increasing the attractiveness of the production of renewable energy is also a need to internalize all external costs of pollution by the manufacturers of energy from traditional sources. Providing state aid in the energy sector should also help achieve three strategic objectives of ensuring security of energy supply, ensuring competition in the energy market and to meet the increasingly sophisticated requirements of environmental protection (Zajdler 2002, 26).

On the other hand, we must remember about the general prohibition of granting state aid. The support may indeed favor of the beneficiaries in relation to these entities, which do not receive such support. Therefore, in the European Union operates a general ban on the granting state aid beyond specific exemptions. One of these exceptions is to support the achievement of environmental objectives, and within them of renewable energy sources. One should however note that often the promotion of renewable energy can have a potentially negative impact on the environment. One such example are hydropower plants when they are not properly designed can cause harm to fish. This is because of the need of water damming, which implies that the fish flowing down injure or even die. A threat to the environment is the also construction of wind turbines. The collision with them killed many birds. However, these disadvantages of ob- 
taining energy from renewable sources are not able to reduce the positive impact of energy production from renewable energy sources on the environment.

\section{ECONOMIC REASONS FOR GRANTING AID IN THE FIELD OF ENVIRONMENTAL PROTECTION}

For economic reasons granting state aid in the field of renewable energy sources can include above all the presence of market failures, the presence of the multiplier effect, encouraging the conduct of investment and the need to restore the production environment (Bartniczak 2007, 17). The most important reasons for the granting of state aid is the existence of market failures [11, p. 11] which could include the presence of external costs and public goods [13, p. 163]. The rationale for granting state aid is therefore no possibility of full internalisation of external costs [15, p. 146], and hence the full implementation of the "polluter pays" principle. According to it, in all these cases, where it's possible to establish clear accountability for the use and pollution of the natural environment of this activity costs should be borne by the offender. There the view that aid must not violate this rule, if the polluter is entirely responsible for their emissions, while state aid supports the adaptation to the polluter pays principle or allow tightening of the protection requirements. The second market failure actuated in the context of state aid for purposes related to the protection of the environment is the existence of public goods or such goods, which for natural reasons (physical characteristics) can serve the local community or society as a whole. These goods are consumed egalitarian by all members of a given community. The fact that the use of a pure public good by one person may not restrict access to the good of another person, this applies to both the quantity and quality of the goods (Owsiak 2000,26). The need to access each of citizens to public goods, in this case environmental resources gives rise to a deeper state intervention in environmental protection. If it be said that the quality of the environment is a public good that steps taken by the state in order to control pollution, and environmental policy itself must be seen as efforts to preserve intact the common good (Winiarski 2000, 376).

An important reason is the occurrence of a specific multiplier effect. Supporting entrepreneurs is dependent on investing his own funds in the project (Fiedor 1999, 219). State aid causes consequently, an increase in the funds allocated for the investment. It can be assumed that without incentives in the form of state aid the project would not be realized. 
Providing aid for the purposes of environmental protection may also result from the need to encourage entrepreneurs to carry out the investment, if the entrepreneur is not interested in that because of not obtained through the investment of additional economic benefits, and in a situation where due to the additional outlays can be particularly important effects environmental protection (Borkowska 1985, 156).

\section{ADMISSIBILITY OF GRANTING STATE AID TO RENEWABLE ENERGY SOURCES}

In Community guidelines for environmental protection (Community guidelines 2008) we can read that on the promotion of renewable energy sources can be allocated investment and operating.

The intensity of investment aid for small companies may not exceed $80 \%$ of eligible costs for medium $70 \%$ and $60 \%$ for large. There is also the possibility of obtaining support at the level of $100 \%$ of eligible costs. Provided, however, provide support for the bidding process with the principles of competition and based on clear and transparent criteria. In order to qualify as eligible costs is to reduce them to the extra investment costs borne by the beneficiary compared to a conventional power plant or a conventional heating system with the same capacity in terms of the effective production of energy.

Operating aid for the production of energy from renewable sources can be justified in order to cover the difference between the cost of producing energy from renewable sources and the market price of the type of energy. These provisions relate to the production of energy from renewable sources, both to its subsequent sale on the market, as well as for the company's own. Operating aid may be granted in three different ways. In the first situation, you may grant operating aid to compensate for the difference between the cost of producing energy from renewable sources, including depreciation of extra investments for environmental protection, and the market price of such energy. In additional conditions indicate that operating aid may be granted to full-time depreciation and additional energy produced by the plant is not eligible for support. Where aid is granted on the above principles to determine the production costs of operating aid must be reduced by investment aid which the firm received. Specific solutions are used in relation to the biomass. Biomass production is closely connected with the relatively low investment costs but high operating costs. Because of that you can receive operating aid exceeding the amount of investment where a Member State will be able to indicate that the total costs incurred 
by the company after plant depreciation are still higher than the market price of energy. The second option allows the granting of aid to support renewable energy sources by using market mechanisms such as green certificates or tenders. These mechanisms allow all producers of renewable energy to benefit indirectly from guaranteed demand for energy produced by them at a price higher than the market price of conventional energy. Price of green certificates is not fixed in advance but depends on supply and demand. In a situation where these mechanisms are state aid can be considered compatible with the common market if a Member State demonstrates that the aid is critical to ensure the viability of renewable energy sources and, ultimately, will not lead to overcompensation and will not discourage energy producers renewable sources by becoming more competitive. In the third option, aid may be granted in the case of gradual reduction in the first year to $100 \%$ of additional costs falling to 0 until the end of the fifth year. In a situation where there will be gradually reduced its intensity must not exceed $50 \%$ of the additional costs.

The rationale for the provision of such support may be the lack of mandatory Community standards relating to the share of energy from renewable sources for individual companies.

In 2012, the European Commission conducted a consultation on the need to amend the admissibility of granting state aid in the field of environmental protection $^{2}$. As a result of these consultations will gather information that will be used by the European Commission in order to better target aid to the achievement of the objectives of environmental protection. In the case of renewable energy sources were consulted, for example, issues related to the effectiveness of the instruments of what type of aid is often used (investment aid or operating) and which of the options for operating aid is the most common. Answers to the question about the type of the granted aid answered 11 Member States. Summary used by them types of state aid, includes tab. 1

Table 1. Types of support of renewable energy sources in selected Member States

\begin{tabular}{|l|c|c|}
\hline \hline \multicolumn{1}{|c|}{ Country } & Investment aid & Operating aid \\
\hline \hline Austria & + & + \\
\hline Czech Republic & + & + \\
\hline
\end{tabular}

2 Information on the consultation can be found at http://ec.europa.eu/competition/ consultations/2012_state_aid_environment/index_pl.html. 


\begin{tabular}{|l|c|c|}
\hline \hline \multicolumn{1}{|c|}{ Country } & Investment aid & Operating aid \\
\hline \hline Estonia & + & \\
\hline Ireland & + & + \\
\hline Latwia & + & + \\
\hline Lithuania & + & + \\
\hline Norway & + & + \\
\hline Poland & + & + \\
\hline Romania & + & + \\
\hline United Kingdom & & + \\
\hline \hline
\end{tabular}

S o u r c e : own study based on: State aid modernization, http://ec.europa.eu/competition/state_ aid/modernisation/index_en.html.

The answers showed that the four countries provided both investment and operating aid and 3 only support in the form of investment or operating. For example the UK introduced program "Renewable obligation certificates (ROCs) for renewable". This program used market-based instrument where targets for production volumes are fixed in advance but where the price is set by market participants (State aid N 414/2008). In Austria we can find the scheme which which used feed-in tariffs to support renewable electricity production. Support is granted where the price rather than the quantity of renewable energy is set (State aid N 47/2008). In Austria we can also find a program by which exempted energy intensive businesses from contributing to buying green electricity (State aid C 24/2009). Germany provides tax reductions for biofuels (State aid N 553/2008). A similar program operated in Poland (State aid N 580/2005).

\section{EXAMPLES OF POLISH SCHEMES}

In the case of Polish aid program works associated with biofuels began in November 2005 and eventually the program was approved by the European Commission in March 82007 (State aid N 580/2005). The scheme reduces excise duty for biofuels produced from biomass. The aim of the program is to encourage the use of biofuels made from biomass. This is to contribute to increase the use of environmentally friendly fuels to reduce greenhouse gas emissions. Exemption from excise duty on biofuels is granted to all companies meeting the following requirements: 
1. the acquired biofuels must be used as fuels;

2. if the firm is producing blended fuels or biofuels, it must provide evidence of the production process of such fuels and on the content of biofuels in the final products;

3. if the firm is trading blended fuels or biofuels, it must provide evidence which allows to determine the amount of biofuels to which the rebates apply.

The program was implemented in the period from 1 January 2007 to 30 April 2011 and its budget was set at 4698 million PLN. The excise tax rebates for petrol and diesel blended with biofuels and for biofuels used as pure fuels are as follows are show in w tab. 2 .

Table 2. The excise tax rebates for petrol and diesel blended with biofuels and for biofuels used as pure fuels are as follows

\begin{tabular}{|l|c|c|}
\hline \multicolumn{1}{|c|}{ fuels } & Normal rate & rabate \\
\hline \hline Biofuels blends with: & 1565 & 1500 \\
\hline petrol & 1180 & \multirow{2}{|c|}{ In PLN per 1000 litre } \\
\hline diesel $(<0,005 \%$ sulphur content) & 1099 & \\
\hline low sulphur $(>0,001 \% \leq 0,005 \%)$ & 1048 & 1680 \\
\hline zero sulphur ( $\leq 0,001 \%)$ & 1882 & \multirow{2}{*}{1000} \\
\hline Biofuels used as pure fuels & & \\
\hline \hline
\end{tabular}

S o u r c e s : State aid N 580/2005 - Poland Excise duty reduction for biofuels.

Existence of state aid within the meaning of Art. 107. 1 TFEU stems from the fact that the reduction of excise duty is granted through state resources. The aim of the measure is to compensate the producers of biofuels parts their costs of production. By reducing the tax liability imposed on products measure favors certain undertakings or the production of certain goods. So the prices of biofuels can be reduced to a level where they can compete with fossil fuels. Because biofuels are used as a substitute for fossil fuels, given the advantage may distort competition in the internal market of the European Union. Because trade fuels is carried out on an international scale, the measure could also affect trade between Member States and therefore constitutes State aid within the meaning of Art. 107 paragraph. 1 of the TFUE. 
Article 107. 3 c TFEU (Consolidated version of the Treaty) provides for an exemption from the general rule of incompatibility in the case of aid to facilitate the development of certain economic activities or of certain economic areas, where such aid does not adversely affect trading conditions to an extent contrary to the common interest. The purpose of proposed measure is to increase the use of environmentally friendly fuels to reduce greenhouse gas emissions. The development of renewable energy, especially biofuels ${ }^{3}$, is promoted since 1985 by a number of Community instruments ${ }^{4}$ and since 2003 by the European Parliament and of the Council 2003/30/EC on the promotion of the use of biofuels or other renewable fuels (Directive 2003). Article 3 of the Directive requires Member States to ensure that on their markets found a minimum proportion of biofuels. It sets an indicative reference value of $5.75 \%$ which should be reached before 31 December 2010. The objectives of this program are in line with EU policy in this area. The Commission has to assess the notified measure in terms of the Community guidelines on state aid for environmental protection (Community guidelines). According to these guidelines can be allowed operating aid for renewable energy production. The Commission is of the view that such aid qualifies for special treatment because of the difficulties that these energy sources met sometimes trying to effectively compete with conventional sources. Accepted is the state to cover the difference between the cost of producing energy from renewable sources and the market price of such energy.

The same applies to biofuels used as additives to mixed products because the proposed exemption from taxes are lower than the applicable rate of excise duty. Assured that such a state of affairs is to maintain throughout the program period, because Poland has confirmed that changes in the prices of fossil fuels and biofuels production costs will be monitored on a quarterly basis and, if necessary, the level of aid will be adjusted. Poland also committed to monitoring changes in the prices of biofuels imported from third countries.

${ }^{3}$ Biofuels are included in the definition of renewable energy sources of Directive 2001/77/EC of the European Parliament and of the Council of 27 September 2001 on the promotion of electricity produced from renewable energy sources in the internal electricity market, OJ L 283 of 27.10.2001.

${ }^{4}$ Among others, the White Paper of 1997 on renewable energies (COM (1997) 599 final of 26.11.1997), the Commission Green paper on energy supply safety in the European Union (COM (2000) 769 of 29.11.2000), the Commission's communication on alternative fuels for road transport and on a set of measures to promote the use of biofuels (COM(2001) 547). 


\section{CONCLUSIONS}

The analysis showed that the state aid can be a useful instrument to support energy production from renewable sources. Without the state aid will not be possible to achieve anticipated levels of production of this type of energy. European Union Member States support the production of energy using both investment and operational aid. Issues relating to the granting of state aid to encourage the production of renewable energy are so important that the European Commission has sought the views of individual member countries on the possible directions of support.

State aid is an instrument to support the production of energy from renewable sources. It should be noted that technological advances for the production of this type of energy is very large. New renewable energy technologies are getting cheaper which means that you should constantly monitor the effectiveness of aid granted. The support is in fact an incentive to produce energy. However, it should be granted for a defined period of time. It should be part of the incentive, and after a certain period of time, it should be withdrawn. This solution was used in the case of the analyzed Polish aid program. State aid was to fulfill the role of incentives, and then abandoned her for the award.

\section{REFERENCES}

Brodecki Z. (2004), Konkurencja, LexisNexis, Warszawa, 124.

Community guidelines on state aid in environment protection, OJ C 82/2008.

Consolidated version of the Treaty on the Functioning of the European Union.

Directive 2003/30/EC of the European Parliament and of the Council of 8 may 2003 on the promotion of the use of biofuels or other renewable fuels for transport.

Hancher L., Ottervanger T., Slot P.J. (2012), EU State Aids, Sweet \& Maxwell, 30.

Modzelewska-Wąchal E., Pełka P., Stasiak M. (2001), Pomoc publiczna dla przedsiębiorców i jej nadzorowanie, LexisNexis, Warszawa, 33-34.

Pełka P., Stasiak M. (2002), Pomoc publiczna dla przedsiębiorców w Unii Europejskiej, Difin, Warszawa, 114-115.

State aid C 24/2009 (ex-N 446/2008) - Austria The Austrian Green Electricity Act - Aid to the Producers of Green Electricity and Aid to Large Electricity Consumers.

State aid N 414/2008 - UK Renewables Obligation - Introduction of a banding mechanism.

State aid N 47/2008 - Austria Modification of feed-in tariffs for electricity from renewable sources under the Austrian Green Electricity Act. 
State aid N 553/2008 - Germany Amendment to Aid Scheme for Tax Rebates for Biofuels (DE).

State aid N 580/2005 - Poland Excise Duty reduction for Biofuels.

Zajdler R. (2002), Wsparcie Unii Europejskiej dla projektów energetycznych w Polsce, Prawo Unii Europejskiej, 6, 26. 
